\title{
Area change of glaciers in the Canadian Rocky Mountains, 1919 to 2006
}

\author{
C. Tennant ${ }^{1}$, B. Menounos ${ }^{1,2}$, R. Wheate ${ }^{1,2}$, and J. J. Clague $^{3}$ \\ ${ }^{1}$ Geography Program, University of Northern British Columbia, Prince George, British Columbia, V2N 4Z9, Canada \\ ${ }^{2}$ Natural Resources and Environmental Studies Institute, University of Northern British Columbia, \\ Prince George, British Columbia, V2N 4Z9, Canada \\ ${ }^{3}$ Department of Earth Sciences, Simon Fraser University, Burnaby, British Columbia, V5A 1S6, Canada
}

Correspondence to: C. Tennant (tennant@unbc.ca)

Received: 5 June 2012 - Published in The Cryosphere Discuss.: 9 July 2012

Revised: 30 November 2012 - Accepted: 8 December 2012 - Published: 20 December 2012

\begin{abstract}
Glaciers in the Canadian Rocky Mountains constitute an important freshwater resource. To enhance our understanding of the influence climate and local topography have on glacier area, large numbers of glaciers of different sizes and attributes need to be monitored over periods of many decades. We used Interprovincial Boundary Commission Survey (IBCS) maps of the Alberta-British Columbia (BC) border (1903-1924), BC Terrain Resource Information Management (TRIM) data (1982-1987), and Landsat Thematic Mapper (TM) and Enhanced Thematic Mapper (ETM+) imagery (2000-2002 and 2006) to document planimetric changes in glacier cover in the central and southern Canadian Rocky Mountains between 1919 and 2006. Over this period, glacier cover in the study area decreased by $590 \pm 70 \mathrm{~km}^{2}(40 \pm 5 \%), 17$ of 523 glaciers disappeared and 124 glaciers fragmented into multiple ice masses. Glaciers smaller than $1.0 \mathrm{~km}^{2}$ experienced the greatest relative area loss $(64 \pm 8 \%)$, and relative area loss is more variable with small glaciers, suggesting that the local topographic setting controls the response of these glaciers to climate change. Small glaciers with low slopes, low mean/median elevations, south to west aspects, and high insolation experienced the largest reduction in area. Similar rates of area change characterize the periods 1919-1985 and $1985-2001 ;-6.3 \pm 0.6 \mathrm{~km}^{2} \mathrm{yr}^{-1}\left(-0.4 \pm 0.1 \% \mathrm{yr}^{-1}\right)$ and $-5.0 \pm 0.5 \mathrm{~km}^{2} \mathrm{yr}^{-1}\left(-0.5 \pm 0.1 \% \mathrm{yr}^{-1}\right)$, respectively. The rate of area loss, however, increased over the period 2001$2006 ;-19.3 \pm 2.4 \mathrm{~km}^{2} \mathrm{yr}^{-1}\left(-2.0 \pm 0.2 \% \mathrm{yr}^{-1}\right)$. Applying size class-specific scaling factors, we estimate a total reduction in glacier cover in the central and southern Canadian Rocky Mountains for the period 1919-2006 of $750 \mathrm{~km}^{2}$ (30\%).
\end{abstract}

\section{Introduction}

Glaciers in the Canadian Rocky Mountains constitute an important freshwater resource. Glacier meltwater flows into four major watersheds, those of the Mackenzie, Nelson, Fraser, and Columbia river basins and drains into the Arctic, Atlantic, and Pacific oceans. The contribution of meltwater to total discharge may be low, but glacier runoff supplements summer flow and regulates stream temperature, both of which are important for aquatic ecosystems, irrigation, industry, hydro power and human consumption (Henoch, 1971; Barry, 2006; Granshaw and Fountain, 2006; Stahl and Moore, 2006; Moore et al., 2009). Marshall et al. (2011) quantify summer contributions from glaciers in the Canadian Rocky Mountains east of the Continental Divide at $0.8 \%$ to $7.4 \%$ at downstream sites in the Canadian prairies. Jost et al. (2012) and Jiskoot and Mueller (2012) estimate that the late summer contribution from glaciers west of the Continental Divide to the upper Columbia River basin is ca. $25 \%$. As glaciers retreat, there is an initial increase in runoff followed by a decline as ice volume is lost; declining glacier runoff is likely now occurring in the Canadian Rocky Mountains (Moore and Demuth, 2001; Moore et al., 2009; Marshall et al., 2011; Kienzle et al., 2012).

Changes in glacier extent are inextricably linked with climate. Meteorological conditions influence a glacier's mass balance on a seasonal or annual time scale and translate into changes in area over a decadal time scale, depending on a glacier's response time (Jóhannesson et al., 1989; Dyurgerov and Bahr, 1999; Dyurgerov and Meier, 2000; Barry, 2006; Pelto, 2006). A glacier's response to climate, however, is complicated by local topography and by individual glacier 
attributes, such as elevation, slope, and aspect. To enhance our understanding of the influence these properties have on glacier area, large numbers of glaciers of different sizes and attributes need to be monitored over periods of many decades. Satellite imagery provides a means for comprehensive, uniform, and frequent monitoring of glaciers globally (Raup et al., 2007), and extents of glaciers from around the world have been compiled by the Global Land Ice Measurements from Space program (GLIMS; http://www.glims.org). An inventory of western Canadian glaciers for the period 1985-2005 completed by Bolch et al. (2010) is included in the GLIMS database. This inventory includes all glaciers in the Canadian Rocky Mountains, but it is temporally limited.

Glacier area measurements in the Canadian Rocky Mountains prior to the beginning of satellite imagery acquisition are generally limited to a few select glaciers (Ommanney, 2002) with the exception of government mapping projects. One of the earliest map series is the Interprovincial Boundary Commission Survey (IBCS) maps of the Alberta-British Columbia (BC) border. These maps were created between 1903 and 1924, using oblique terrestrial photographs taken from mountain ridges (Interprovincial Boundary Commission, 1917; Wheeler, 1920). Once properly corrected for topographic distortion and systematic bias, these maps provide an important dataset for extending the glacier inventory of the Canadian Rocky Mountains, thus providing a long-term record of glacier area change.

The objectives of this study are to: (1) calculate changes in glacier cover from 1919 to 2006 for the central and southern Canadian Rocky Mountains; (2) relate changes in area to glacier properties such as slope, aspect, and mean, median, and minimum elevations, and; (3) compare changes in glacier cover to changes in climate.

\section{Study area}

We focus on glaciers in the central and southern Canadian Rocky Mountains that were mapped during the 1903-1924 IBCS of the Alberta-BC border. The Rocky Mountains trend north-northwest and form the Continental Divide between Alberta and BC (Fig. 1). Differential weathering and erosion of uplifted, resistant Paleozoic carbonates and weaker Mesozoic sandstones and shales, and recurrent alpine and continental glaciations, formed the high relief of the region (Heusser, 1956; Osborn et al., 2006). The two highest peaks in the Canadian Rocky Mountains are Mt. Robson (3954 m above sea level, a.s.l.) and Mt. Columbia (3747 m a.s.1.).

Vegetation in this region is dominated by alpine and subalpine plants (Heusser, 1956; BC Ministry of Forests, 1998), and the climate is characterized by long winters, short summers, and high amounts of precipitation, with abundant snowfall (BC Ministry of Forests, 1998). Mean annual temperature ranges from $-6.4{ }^{\circ} \mathrm{C}$ to $-0.2{ }^{\circ} \mathrm{C}$ and total annual precipitation ranges from $730 \mathrm{~mm}$ to $1970 \mathrm{~mm}$. West of the

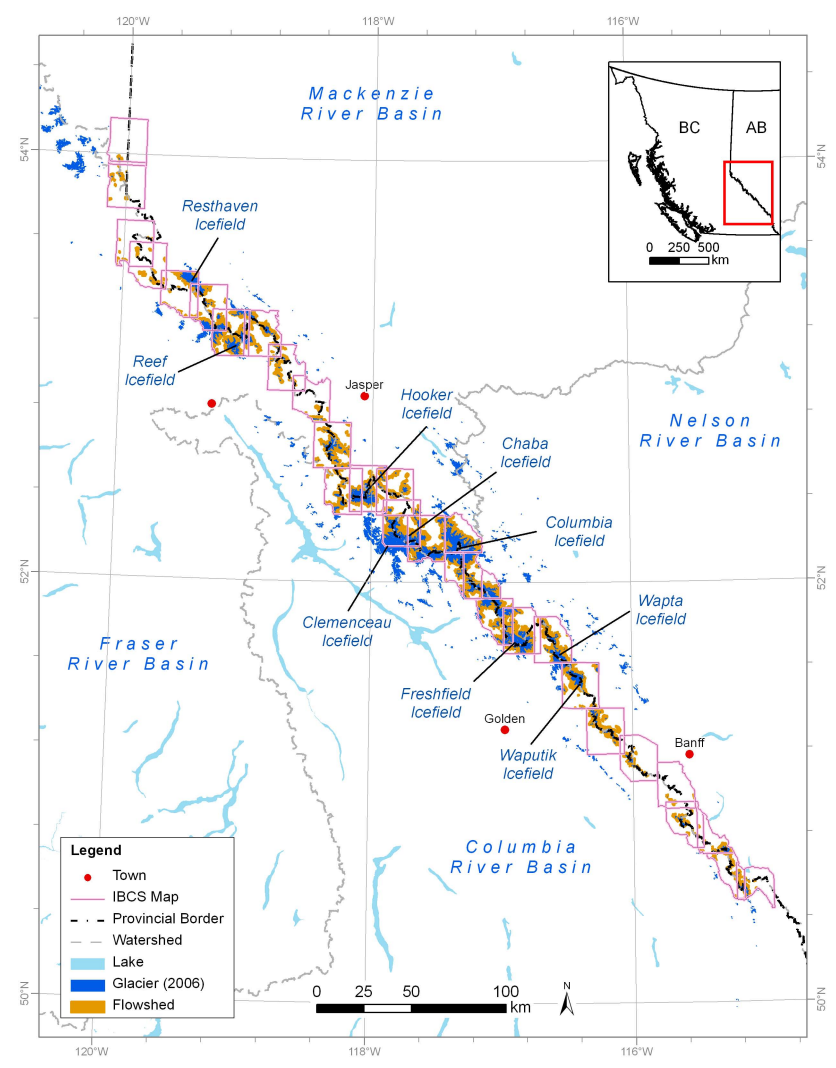

Fig. 1. Glaciers in the central and southern Canadian Rocky Mountains. Glaciers encompassed by the orange flowsheds are the focus of this study and include glaciers mapped by the Interprovincial Boundary Commission Survey between 1903 and 1924.

Continental Divide, climate is strongly influenced by maritime polar air masses; cyclonic storms cross the region from the North Pacific between September and June (Heusser, 1956; Henoch, 1971; Hauer et al., 1997). East of the Divide, continental polar air masses dominate, particularly during winter (Heusser, 1956; Hauer et al., 1997). Shea et al. (2004) suggest spring precipitation, annual temperatures, and winter precipitation are the main factors influencing glacier distribution within the Canadian Rocky Mountains.

In 2006, the area of glaciers in the study area was ca. $900 \mathrm{~km}^{2}$, representing $50 \%$ of the total glacier cover of the central and southern Canadian Rocky Mountains (Bolch et al., 2010). Types of glaciers include valley, cirque, and icefield outlet glaciers with a range of surface and frontal characteristics (Heusser, 1956; Denton, 1975; Ommanney, 2002; Schiefer et al., 2008; Jiskoot et al., 2009; Bolch et al., 2010). Glaciers range in size up to $40 \mathrm{~km}^{2}$, have median elevations around $2500 \mathrm{~m}$ a.s.l., and predominantly face north to northeast (Schiefer et al., 2008). The main icefields from north to south are Resthaven, Reef, Hooker, Chaba, Clemenceau, Columbia, Freshfield, Wapta, and Waputik (Fig. 1). 


\section{Data and methods}

\subsection{Interprovincial Boundary Commission Survey maps}

The IBCS map series comprise 54 maps at a scale of $1: 62500$ with a contour interval of 100 feet. Scanned digital copies of the maps were obtained from Library and Archives Canada (http://www.collectionscanada.gc.ca/ index-e.html). Of the 54 maps, 30 contained glaciers and were used in this analysis.

We rectified the IBCS maps in PCI Geomatica OrthoEngine v.10.2 using a 5th order polynomial transformation model that adjusts the positions of mapped features based on ground control points (GCPs). We collected 25-40 GCPs per map (Fig. 2) from previously orthorectified Landsat Thematic Mapper (TM) and Enhanced Thematic Mapper (ETM+) imagery with errors of $\pm 15 \mathrm{~m}$ and $\pm 50 \mathrm{~m}$, respectively (Bolch et al., 2010). We also used a shaded relief model (hillshading) derived from the BC Terrain Resource Information Management (TRIM) digital elevation model (DEM; Table 1) with a horizontal error of $\pm 10 \mathrm{~m}$ and a vertical error of $\pm 5 \mathrm{~m}$ (BC Ministry of Environment, Land and Parks, 1992). Most GCPs were mountain peaks and ridges because they were easy to identify on the maps and are stable, vegetationfree areas. As the polynomial transformation did not use elevation data, we focused on spatially distributed GCPs rather than an altitudinal distribution. However, GCPs from valleys were needed to provide control for glacier termini and map edges. For this purpose, we used the centres of small lakes, as shorelines may have changed over ca. $80 \mathrm{yr}$. The average root mean square errors (RMSE) in the easting and northing of the GCPs were 12.2 and $11.5 \mathrm{~m}$, respectively, with a minimum value of $2.3 \mathrm{~m}$ and a maximum value of $24.9 \mathrm{~m}$. We also visually checked the positions of peaks, ridges, and lakes on the maps against the BC TRIM hillshading and Landsat imagery. If there were noticeable offsets, we adjusted the GCPs to minimize the offsets.

\subsection{Data collection}

We manually digitized glacier extents and contours on the rectified IBCS maps. There are no glacier boundary lines on the maps, although the contour lines over glaciers are blue, rather than brown. We therefore digitized around the blue contours to delineate glacier extents (Fig. 3). Where maps overlapped, we digitized glacier extents and contours from the map that exhibited the least offset from the Landsat imagery. We also generated a DEM (Digital Elevation Model) by interpolation of the contours from the historic maps using ArcGIS v.9.3, from which we extracted glacier properties.

We compared glacier extents on the IBCS maps with glacier polygons in the Landsat-based glacier inventory of Western Canada (Bolch et al., 2010). Glacier extents are available for the years 1982-1987, 2000-2002, and 2006 (Ta-
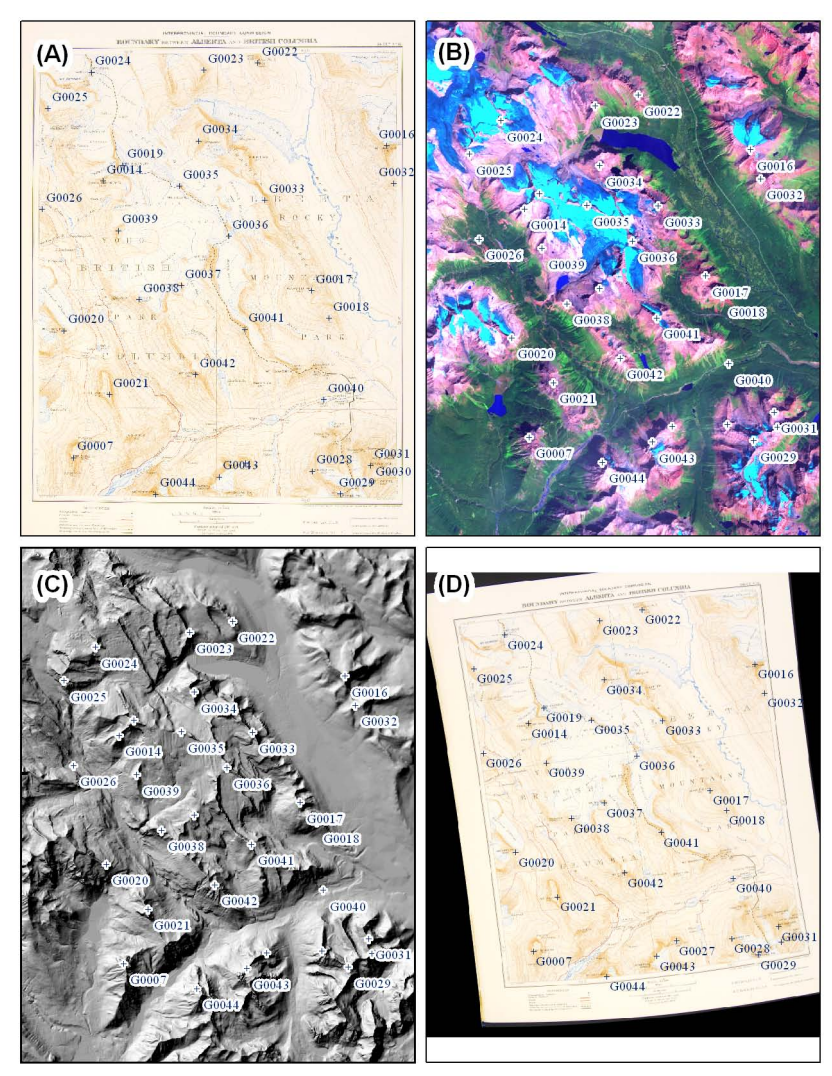

Fig. 2. (A) Example of a raw IBCS map that was rectified using 30 GCPs collected from (B) previously rectified Landsat imagery and (C) BC TRIM hillshading to produce (D) a rectified map from which glacier extents and contours were extracted.

ble 1). We clipped glacier extents to the IBCS map extents and separated into glacier flowsheds modified from Bolch et al. (2010). Flowsheds are based on drainage basins and, depending on a specific period, may contain one or several glaciers.

We used the median year of the glacier coverage (1919, 1985, 2001, and 2006) to define approximate acquisition dates for the glacier data as a whole, although individual area change and rates are based on the actual acquisition year for a given flowshed. In the case of the IBCS data, where two maps may have been used to delineate a given flowshed, we used the average date of the maps.

\subsection{Error analysis}

Mapping and printing errors (21\% of flowsheds) were evident in the IBCS maps (Fig. 4a-c). In some cases, glacier contours were shifted in relation to the land contours, making the location of the glacier margin difficult to determine. In these cases, we placed the glacier margin halfway between the shift of the land and glacier contours. The terminus of Wales Glacier is missing from the IBCS map (Fig. 4b), where the cartographer estimated it due to incomplete photographic 
Table 1. Data used to rectify the IBCS maps and to assess glacier change between 1919 and 2006.

\begin{tabular}{|c|c|c|}
\hline $\begin{array}{l}\text { Year } \\
\text { (date/median) }\end{array}$ & $\begin{array}{l}\text { Data source } \\
\text { (path/row) }\end{array}$ & $\begin{array}{r}\text { Resolution/ } \\
\text { Scale }\end{array}$ \\
\hline \multicolumn{3}{|c|}{ Reference data for GCP collection } \\
\hline $1982-1987$ & BC TRIM + Alberta DEM hillshading & $25 \mathrm{~m}$ \\
\hline 1985 (31 Jul) & Landsat 5 TM (45/23) & $30 \mathrm{~m}$ \\
\hline 2001 (14 Sep) & Landsat 7 ETM+ $(44 / 24)$ & $30 \mathrm{~m}$ \\
\hline 2004 (18 Aug) & Landsat 5 TM (47/22) & $30 \mathrm{~m}$ \\
\hline 2004 (28 Sep) & Landsat 5 TM (46/23) & $30 \mathrm{~m}$ \\
\hline 2006 (18 Aug) & Landsat 5 TM (43/24-25) & $30 \mathrm{~m}$ \\
\hline 2006 (19 Aug) & Landsat 5 TM (44/24) & $30 \mathrm{~m}$ \\
\hline 2006 (26 Aug) & Landsat 5 TM (45/24) & $30 \mathrm{~m}$ \\
\hline \multicolumn{3}{|l|}{ Extents } \\
\hline 1903-1924 (1919) & IBCS & $1: 62500$ \\
\hline $1982-1987(1985)^{*}$ & BC TRIM/Landsat 5 TM & $1: 20000 / 30 \mathrm{~m}$ \\
\hline $2000-2002(2001)^{*}$ & Landsat 7 ETM+ & $30 \mathrm{~m}$ \\
\hline $2006(2006)^{*}$ & Landsat 5 TM & $30 \mathrm{~m}$ \\
\hline \multicolumn{3}{|l|}{ DEMs } \\
\hline 1903-1924 (1919) & IBCS contours & $100 \mathrm{~m}$ \\
\hline $1982-1987(1985)^{*}$ & BC TRIM + Alberta mass points & $25 \mathrm{~m}$ \\
\hline 1999 (1999) & SRTM & $90 \mathrm{~m}$ \\
\hline
\end{tabular}

* See Bolch et al. (2010) for more detailed information on data sources. Glacier extents are on the GLIMS website (http://www.glims.org).

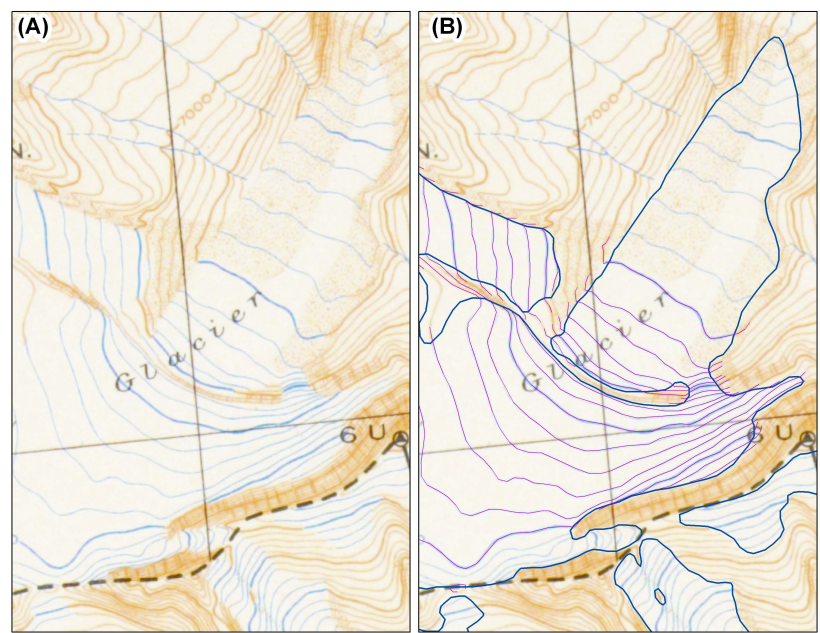

Fig. 3. Example of (A) a glacier on the IBCS maps and (B) its digitized extents and contours.

coverage (Wheeler, 1988). Six percent of the glaciers extended beyond the limits of the map sheet. These situations pose a problem in calculating area change for a given flowshed, thus we eliminated them from the analysis.
When we compared IBCS glacier extents with those from 1985,2001 , and 2006, we noticed missing glaciers in one or more of the glacier inventories. In these cases, we manually digitized the extents from the original Landsat imagery that had been used to create the glacier inventory (see Bolch et al., 2010, for a list of Landsat imagery). We also assembled and edited a ca. 2001 inventory of glaciers for the central Canadian Rocky Mountains, because no finished inventory for this epoch existed in the data originally assembled by Bolch et al. (2010) (Fig. 4d). We overlaid each glacier on the imagery and manually modified its extents if it had been incorrectly mapped. For the 1985 extents, we did not have a complete set of Landsat images coverage to check the BC TRIM data, thus observed errors $(4 \%)$ or missing glaciers $(8 \%)$ could not be corrected (Fig. 4e). Some glacier extents $(5 \%)$ could not be added or corrected due to shadows and cloud cover (Fig. 4f).

To reduce potential bias resulting from these mapping errors and inconsistencies due to missing glaciers, we did not compare changes in glacier area in flowsheds with problematic glaciers and removed them before conducting area change analysis. Of the original 937 flowsheds, 414 were removed ( $44 \%$ of the flowsheds or $17 \%$ of the glacier area), leaving 523 flowsheds for analysis.

The error terms for glacier extents in the glacier inventory of Western Canada are 3-4 \% (Bolch et al., 2010). However, we had to modify extents for snow cover, shadows, and missing glaciers, and so we calculated new error terms 
Table 2. Error estimates for area (year) and area change (period).

\begin{tabular}{rrrr}
\hline Year & $\begin{array}{r}\text { Error }^{\mathrm{a}} \\
(\%)\end{array}$ & Period & $\begin{array}{r}\text { Error }^{\mathrm{b}} \\
(\%)\end{array}$ \\
\hline 1919 & 11.2 & $1919-1985$ & 9.8 \\
1985 & 7.8 & $1985-2001$ & 9.8 \\
2001 & 11.5 & $2001-2006$ & 12.5 \\
2006 & 13.3 & $1919-2006$ & 12.6 \\
\hline
\end{tabular}

${ }^{a}$ Mean glacier extent error estimates calculated from individual glacier buffers.

$\mathrm{b}$ Mean RMSE calculated from the error estimates of the two differenced extents.

using a buffer method similar to that in Granshaw and Fountain (2006) and Bolch et al. (2010). The error term for the 1919 extents is based on a buffer incorporating the RMSE of the map rectification $(16 \mathrm{~m})$ and the digitizing error equal to half the width of a contour line $(7.5 \mathrm{~m})$. For the imagebased glacier inventories, we used a buffer equal to half the resolution of the data (Table 1). The 1985 glacier extents are derived from BC TRIM data and Landsat imagery; in this case, we used a buffer equal to half of the combined resolution $(11 \mathrm{~m})$. Between each period, we calculated a RMSE term using the error estimates from the two years that make up a period. Calculated glacier extent error terms are listed in Table 2 and range from $7.8 \%$ to $13.3 \%$ for the individual years and from $9.8 \%$ to $12.6 \%$ for the periods.

\subsection{Glacier change analysis}

For each flowshed, we calculated the glacierized area and the number of ice masses. We determined the mean, median, and minimum elevations of glaciers within each flowshed, and derived the mean surface slope and aspect from the DEMs (Table 1) using zonal statistics (Paul et al., 2009). The vertical uncertainties of the 1919 IBCS, BCTRIM/Alberta, and SRTM DEMs are $\pm 40 \mathrm{~m}, \pm 5 \mathrm{~m}$ (BC Ministry of Environment, Land and Parks, 1992), and $\pm 10 \mathrm{~m}$ (Farr et al., 2007), respectively, although these values may be higher in the accumulation areas due to poor contrast of the original aerial and terrestrial photographs or radar penetration (Bolch et al., 2010). Using the Solar Radiation tool (algorithms developed by Fu and Rich, 2002) in ArcGIS v.9.3, we produced a surface of clear sky incoming solar radiation (insolation, $\mathrm{W} \mathrm{h} \mathrm{m}^{-2}$ ) from the BC TRIM/Alberta DEM. We calculated absolute $\left(\mathrm{km}^{2}\right)$ and relative $(\%)$ area change and rates between successive years, and compared them with the properties mentioned above.

\subsection{Climate data}

We obtained monthly minimum, mean, and maximum temperatures and monthly total precipitation from 1901 to 2006 at the centre of each glacier, based on latitude, longitude, and elevation, using the ClimateWNA
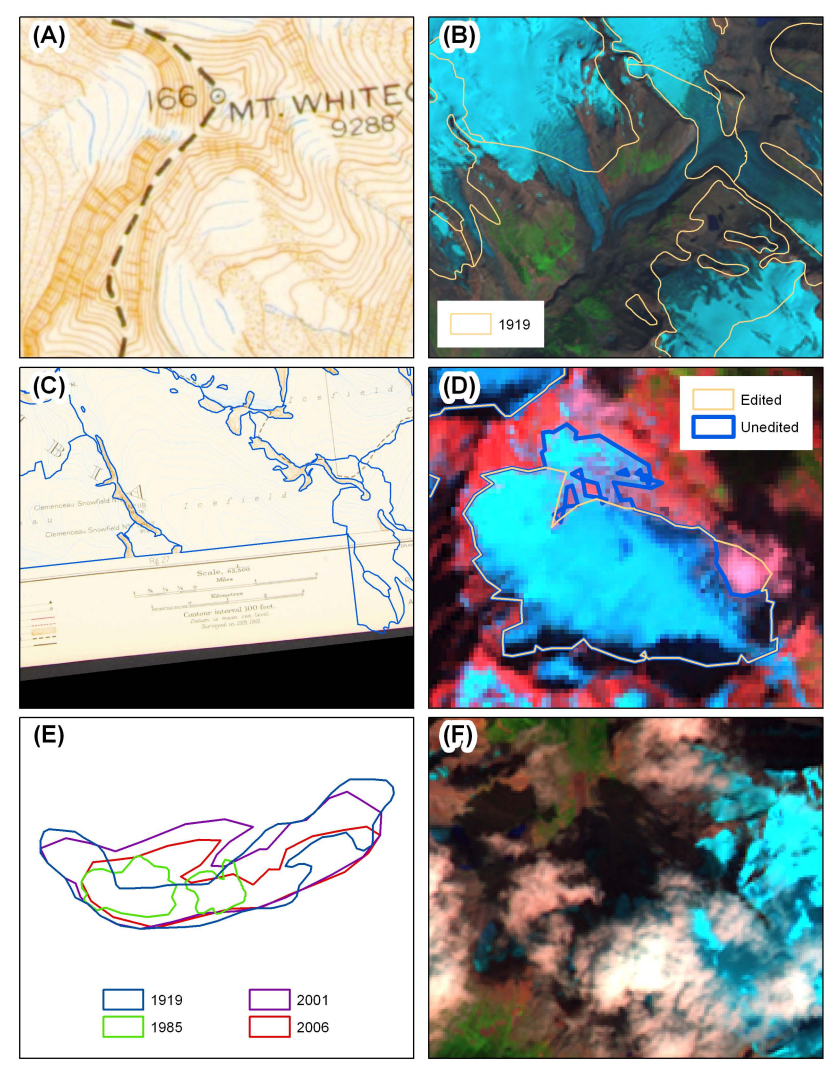

Fig. 4. Errors and problems associated with glacier extents. (A) Offset 1919 glacier contours. (B) Mismapped 1919 extents. (C) Cut off glaciers. (D) Unedited 2001 extents. (E) Mismapped 1985 and 1919 extents. (F) Shadow and cloud cover.

v.4.62 program (http://www.genetics.forestry.ubc.ca/cfcg/ ClimateWNA/ClimateWNA.html). This program extracts climate data at specific locations from downscaled PRISM and historical data using anomalies (Wang et al., 2012). Anomaly surfaces are derived from interpolated historical data created by Mitchell and Jones (2005) and from a baseline reference grid ( $2.5 \mathrm{arcmin})$ of monthly climate data for the period 1961-1990 generated by PRISM (Daly et al., 2002). The program uses bilinear interpolation and monthly variable lapse-rate elevation adjustments to integrate the historical anomaly surfaces and the baseline grid and downscale the climate data at a specific location (Wang et al., 2006, 2012; Mbogga et al., 2009). More detailed information on the downscaling methodology can be found in Wang et al. (2012). The ClimateWNA data has not been validated for downscaling and statistical extrapolation to individual glaciers. However, we use the data to provide a general picture of the climate over the period of the study.

We calculated total annual precipitation based on the hydrologic year, October to September, as well as total precipitation during the ablation (May to September) and accumulation (October to April) seasons. Total precipitation was used because snow is common throughout the year at 
high elevation. We determined minimum, mean, and maximum annual temperature, in addition to ablation and accumulation season temperature. We derived temperature and precipitation anomalies from the 1919-2006 annual and seasonal means and grouped them into three periods: 19191985, 1985-2001, and 2001-2006. We chose these three periods to match the periods of area changes and rates, being well aware that glacier changes in area are always a delayed reaction to climate change.

\section{Results}

\subsection{Glacier properties}

We inventoried 569 glaciers in 523 flowsheds along the Alberta-BC border from the IBCS maps, which constitutes about $50 \%$ of the glacier area in the central and southern Canadian Rocky Mountains. The total area of glacier ice in the study area in 1919 was $1470 \pm 160 \mathrm{~km}^{2}$ (Table 3). Each flowshed represents the total area of ice within it and may include multiple individual ice masses (e.g. an avalanche-fed glacier with a separate accumulation area or disconnected tributary glaciers). For the 1919 data, however, the glacierized area within a flowshed is considered to represent a single body of ice.

Glacierized areas and numbers of glaciers in 1919 were determined for different regions within the study area, for the east and west sides of the Continental Divide, and for river basins, aspect, and glacier size (Fig. 5). Areas with the largest total glacier area and glacier numbers were the southern Canadian Rockies, the east side of the Continental Divide, and the Columbia River Basin. In 1919, most glaciers faced north and northeast; the fewest glaciers faced south to west. We separated glaciers into six size classes based on their 1919 areas: $0.05-0.1 \mathrm{~km}^{2}, 0.1-0.5 \mathrm{~km}^{2}, 0.5-1.0 \mathrm{~km}^{2}, 1.0$ $5.0 \mathrm{~km}^{2}, 5.0-10.0 \mathrm{~km}^{2}$, and $>10.0 \mathrm{~km}^{2}$. In 1919 , the 1.0 $5.0 \mathrm{~km}^{2}$ size class contained the greatest number of glaciers (37\% of the total). The three classes of glaciers smaller than $1.0 \mathrm{~km}^{2}$ accounted for $49 \%$ of the total number. Glaciers in the $>10 \mathrm{~km}^{2}$ size class had the largest composite area (41\%).

We compared the 1919 glacier distribution to the distribution in the glacier inventory of the entire central and southern Canadian Rocky Mountains created by Bolch et al. (2010). Using a chi-squared test, we determined that the area distributions are similar for all categories except for the regional and Continental Divide categories ( $p \leq 0.05)$. For the glacier number distributions (Fig. 5a), only the size categories are significantly different between the two datasets $(p \leq 0.05)$.

In 1919, glacier areas ranged in size from $0.06 \pm 0.01 \mathrm{~km}^{2}$ to $50 \pm 6 \mathrm{~km}^{2}$ (Freshfield Glacier); the mean glacier area was $2.9 \pm 0.3 \mathrm{~km}^{2}$. Glacier ice was present between elevations of 1410 and $3860 \mathrm{~m}$ a.s.l. and glaciers had a mean elevation range of $620 \mathrm{~m}$. Both mean and median elevations of the glaciers were $2470 \mathrm{~m}$ a.s.l.; glaciers with the highest mean

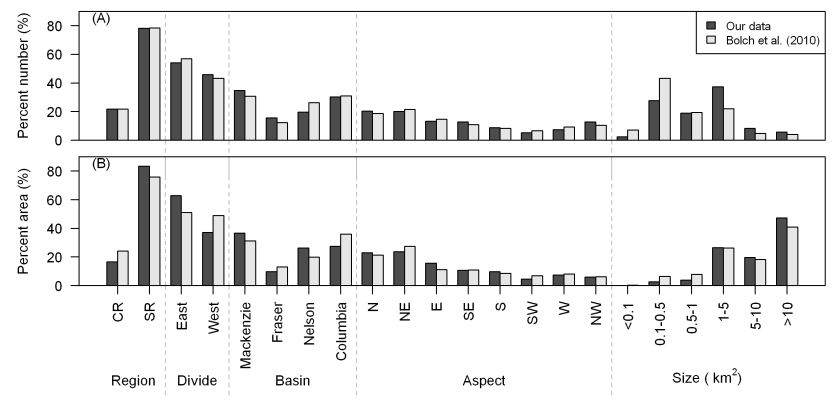

Fig. 5. (A) Number and (B) area distributions of glaciers analyzed in our study and all glaciers in the central and southern Canadian Rocky Mountains mapped by Bolch et al. (2010).

elevations had northern aspects. The mean surface slope of glaciers was $19^{\circ}$, with a range from $6^{\circ}$ to $46^{\circ}$.

By 2006, glacier cover in the study area had decreased to $880 \pm 120 \mathrm{~km}^{2}$, a loss of $590 \pm 70 \mathrm{~km}^{2}$ since 1919. The number of ice masses increased to 724 due to the disintegration of 124 glaciers (Fig. 6). Thirteen ice masses disappeared from flowsheds still containing glaciers in 2006, and 17 glaciers disappeared completely. Fifteen of the these 17 glaciers disappeared between 1919 and 1985; the remaining two disappeared between 2001 and 2006. Fourteen of the 17 glaciers that disappeared were smaller than $0.5 \mathrm{~km}^{2}$. For these 17 glaciers, surface slopes ranged from $11^{\circ}$ to $36^{\circ}$, with a mean of $20^{\circ}$. The mean elevation ranges were between $96 \mathrm{~m}$ and $460 \mathrm{~m}$. Mean and median elevations of the glaciers that disappeared prior to 2006 were below $2500 \mathrm{~m}$ a.s.l.

Between 1919 and 2006, mean glacierized area per flowshed decreased to $1.7 \pm 0.2 \mathrm{~km}^{2}$. Elevation data are not available for 2006, thus elevations, surface slope, and aspect are based on data from 1999. At that time, glaciers existed at elevations between 1570 and 3660 ma.s.l., a decrease in the elevation range from that in 1919. From 1919 to 2006, mean and median elevations increased $60 \mathrm{~m}$, mean surface slope increased $2^{\circ}$, and the distribution of glaciers by aspect did not change.

\subsection{Area change}

Between 1919 and 2006, the total glacier cover in the study area decreased by $590 \pm 70 \mathrm{~km}^{2}(40 \pm 5 \%)$ at a rate of $-6.8 \pm 0.9 \mathrm{~km}^{2} \mathrm{yr}^{-1}\left(-0.5 \pm 0.1 \% \mathrm{yr}^{-1}\right)$. The greatest absolute area loss was in the $1.0-5.0 \mathrm{~km}^{2}$ size class (Table 3 ), but relative area loss was greatest in the $0.5-1.0 \mathrm{~km}^{2}$ size class. Glaciers smaller than $1.0 \mathrm{~km}^{2}$ lost on average $64 \pm 8 \%$ of their area. Large glaciers $\left(>10.0 \mathrm{~km}^{2}\right)$ had the smallest relative area loss. Relative area change becomes increasingly variable with smaller glaciers (Fig. 6).

Total absolute and relative rates of glacier area change in the study area are given in Table 3. The median absolute rates of glacier area change for the periods 1919-1985 and $1985-2001$ are similar, $-0.0065 \pm 0.0006 \mathrm{~km}^{2} \mathrm{yr}^{-1}$ 
Table 3. Glacier data for the period 1919-2006.

\begin{tabular}{|c|c|c|c|c|c|c|c|c|c|c|c|c|c|c|c|c|c|}
\hline \multirow{2}{*}{$\begin{array}{l}\text { Class } \\
\left(\mathrm{km}^{2}\right)\end{array}$} & \multirow[b]{2}{*}{ Count } & \multicolumn{4}{|c|}{ Area $\left(\mathrm{km}^{2}\right)$} & \multicolumn{2}{|c|}{$\begin{array}{c}1919-1985 \\
\text { change }\end{array}$} & \multicolumn{2}{|c|}{$\begin{array}{c}\text { 1985-2001 } \\
\text { change }\end{array}$} & \multicolumn{2}{|c|}{$\begin{array}{c}2001-2006 \\
\text { change }\end{array}$} & \multicolumn{2}{|c|}{$\begin{array}{c}\text { 1919-2006 } \\
\text { change }\end{array}$} & \multirow[b]{2}{*}{ Count } & \multicolumn{2}{|c|}{ Area $\left(\mathrm{km}^{2}\right)$} & \multirow{2}{*}{$\begin{array}{r}1919-2006 \\
\text { change }^{\mathrm{a}}\end{array}$} \\
\hline & & 1919 & 1985 & 2001 & 2006 & $\left(\mathrm{~km}^{2}\right)$ & $(\%)$ & $\left(\mathrm{km}^{2}\right)$ & $(\%)$ & $\left(\mathrm{km}^{2}\right)$ & $(\%)$ & $\left(\mathrm{km}^{2}\right)$ & $(\%)$ & & 2005 & $1919^{\mathrm{b}}$ & \\
\hline$<0.1$ & 12 & 1.0 & 0.6 & 0.5 & 0.4 & -0.4 & -38.7 & -0.1 & -15.7 & -0.1 & -20.0 & -0.6 & -58.6 & 86 & 6.6 & 10.4 & -3.8 \\
\hline $0.1-0.5$ & 145 & 41.8 & 27.9 & 23.4 & 17.6 & -13.9 & -33.2 & -4.5 & -16.2 & -5.8 & -24.9 & -24.2 & -57.9 & 477 & 124.9 & 197.2 & -72.3 \\
\hline $0.5-1$ & 99 & 74.6 & 40.9 & 33.1 & 24.0 & -33.6 & -45.1 & -7.8 & -19.1 & -9.1 & -27.5 & -50.6 & -67.8 & 215 & 152.0 & 255.1 & -103.1 \\
\hline $1-5$ & 195 & 455.0 & 280.8 & 252.7 & 212.6 & -174.2 & -38.3 & -28.1 & -10.0 & -40.1 & -15.9 & -242.4 & -53.3 & 254 & 546.5 & 837.7 & -291.1 \\
\hline $5-10$ & 43 & 294.3 & 207.3 & 195.4 & 175.1 & -87.0 & -29.6 & -11.9 & -5.7 & -20.2 & -10.3 & -119.1 & -40.5 & 36 & 246.9 & 346.9 & -100.0 \\
\hline$>10$ & 29 & 607.1 & 499.2 & 471.4 & 450.2 & -107.9 & -17.8 & -27.8 & -5.6 & -21.2 & -4.5 & -156.9 & -25.8 & 36 & 684.4 & 861.3 & -176.9 \\
\hline Total & 523 & 1473.7 & 1056.7 & 976.5 & 880.0 & -417.0 & -28.3 & -80.2 & -7.6 & -96.5 & -9.9 & -593.7 & -40.3 & 1104 & 1761.4 & 2508.6 & -747.2 \\
\hline $\operatorname{Rate}\left(\mathrm{yr}^{-1}\right)$ & & & & & & -6.3 & -0.4 & -5.0 & -0.5 & -19.3 & -2.0 & -6.8 & -0.5 & & & & -8.6 \\
\hline
\end{tabular}

a Absolute change in area (column 18) is calculated by multiplying the relative area change (column 14) with the respective area in each class (column 16).

b 1919 area for each size class (column 17) is calculated by subtracting the absolute area change (column 18) from the 2005 area (column 16).

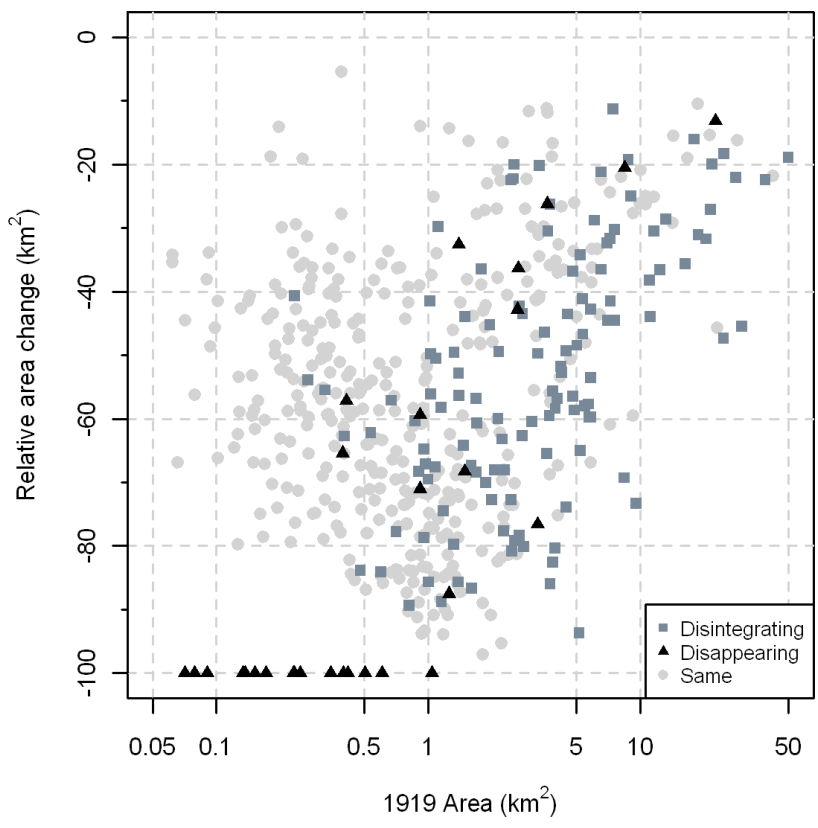

Fig. 6. Plot of 1919-2006 relative area change versus 1919 glacier area. Data are separated into three groups: flowsheds with an increase in the number of ice masses (disintegrating); flowsheds with a decrease in the number of ice masses (disappearing); and no change (same).

and $-0.0047 \pm 0.0005 \mathrm{~km}^{2} \mathrm{yr}^{-1}$, respectively (Fig. 7). Corresponding median relative rates of glacier area change for these two periods are $-0.50 \pm 0.05 \% \mathrm{yr}^{-1}$ and $-0.45 \pm 0.04 \% \mathrm{yr}^{-1}$, respectively. The absolute median rate of area change for the period 2001-2006 is significantly higher, $-0.0200 \pm 0.0025 \mathrm{~km}^{2} \mathrm{yr}^{-1}$; the relative median rate is $-1.67 \pm 0.21 \% \mathrm{yr}^{-1}$. These patterns in absolute and relative rates of area change are consistent across the different glacier size classes.

We estimated the total change in glacier area between 1919 and 2006 for the entire central and southern Canadian Rocky Mountains as inventoried by Bolch et al. (2010), using the size class scaling method of Paul et al. (2004). Because the
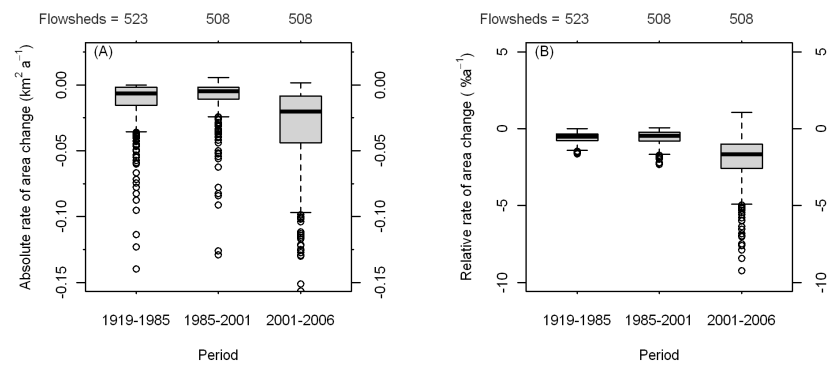

Fig. 7. (A) Absolute and (B) relative rates of area change for glaciers in the Canadian Rocky Mountains, over three periods from 1919 to 2006. Boxes represent the first and third quartiles; the horizontal black line is the median. The whiskers represent data extremes (5th and 95th percentiles) and the circles are outliers (data outside the 5th and 95th percentiles).

distribution of area by size class is similar between the two datasets, we multiplied our relative area change by the area of each size class of the central and southern Canadian Rocky Mountains. We calculated a total area change of $-750 \mathrm{~km}^{2}$ between 1919 and 2006 (Table 3). This change indicates a glacier covered area of $2500 \mathrm{~km}^{2}$ in 1919 .

\subsection{Area change with glacier attributes}

We compared absolute and relative changes in glacier area within the study area to the following glacier attributes: minimum, mean, and median elevations; surface slope; latitude and longitude; and insolation. Over all periods, absolute area changes correlate moderately with minimum elevation (mean $r=0.43, p<0.01$ ) and mean slope (mean $r=0.40$, $p<0.01$ ). This result indicates that glaciers with lower minimum elevations and slopes lost more absolute area. These two properties, however, are also moderately correlated with glacier area $(r=-0.51$ and $r=-0.39$, respectively). Therefore, large glaciers tend to have the lowest minimum elevations and slopes and lost the most area. No moderate or strong correlations exist among any of the attributes and relative changes in glacier area. 
We determined the relative glacier area change from 1919 to 2006 for each attribute class (Fig. 8). Relative area change increased with low mean, and median elevation, small elevation ranges, and high minimum elevations. Glaciers with moderately steep surface slopes had small relative area changes; in contrast, glaciers with slopes $>30^{\circ}$ had a large relative area change. There did not appear to be any trends in relative area change with other glacier attributes including insolation, aspect, region, basin, or position relative to the Continental Divide. We determined the relative area change from 1919 to 2006 for each attribute class for glaciers $<1 \mathrm{~km}^{2}$ (Fig. 8). The trends were similar to those obtained for all glaciers, except for insolation. The $800-850 \mathrm{~kW} \mathrm{~h} \mathrm{~m}^{-2}$ insolation class had the highest relative area change. Glaciers with south to west aspects had greater relative area change than glaciers with north to east aspects.

\subsection{Climate}

Annual temperature anomalies for the period 1919-1985 were ca. $0.1^{\circ} \mathrm{C}$ below the $1919-2006$ mean. Accumulation season temperature anomalies were $-0.2^{\circ} \mathrm{C}$ and annual, accumulation and ablation season minimum temperature anomalies were $-0.3^{\circ} \mathrm{C}$ (Fig. 9). Between 1985 and 2006, minimum temperature anomalies were $0.7^{\circ} \mathrm{C}$ above the 1919-2006 average. Maximum ablation season temperature anomalies were $-0.4{ }^{\circ} \mathrm{C}$ below average, and accumulation season temperature anomalies were $0.4{ }^{\circ} \mathrm{C}$ above average for the period 1985-2001. In the most recent period, 2001-2006, seasonal and annual maximum, mean, and minimum temperature anomalies were $0.5^{\circ} \mathrm{C}$ above the 1919 2006 average.

Annual precipitation anomalies were near $100 \%$ (19192006 average) for the periods 1919-1985 and 1985-2001. Accumulation season precipitation for the period 1985-2001 was ca. 110\% (1919-2006 average). The period 2001-2006 had the lowest precipitation anomalies (ca. $90 \%$ ).

\section{Discussion}

\subsection{Area change}

Total ice cover in our study area, decreased $590 \pm 70 \mathrm{~km}^{2}$ $(40 \pm 5 \%)$ between 1919 and 2006. The sources of uncertainty lie primarily in the IBCS maps where some glaciers may have been incorrectly mapped due to snow cover, or estimated where photographic coverage was incomplete or the perspective was poor (Wheeler, 1988). In addition, shadows, debris cover, snow cover, and clouds introduce uncertainties in all years.

We compared our results to those of Bolch et al. (2010) for the southern and central Canadian Rocky Mountains. A perfect comparison was not expected because we modified and edited the glacier extents and used a subset of their glacier inventory data. Nevertheless, we found good agree-

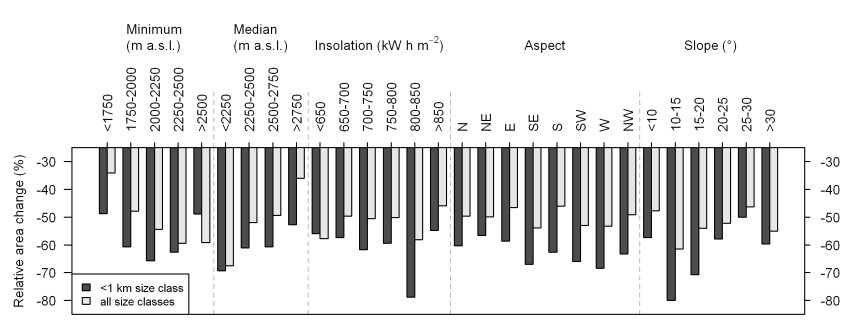

Fig. 8. Relative area change of glaciers in the study area for the period 1919-2006 as a function of different attributes.

ment between our area changes and those of Bolch et al. (2010). Between 1985 and 2005, area changes from Bolch et al. (2010) are $-17.5 \pm 4.1 \%$ and $-14.8 \pm 4.1 \%$ for, respectively, the central and southern Canadian Rocky Mountains regions, similar to our estimates of $-19.6 \pm 3.1 \%$ and $-17.0 \pm 2.7 \%$ for the same period. The rates of Bolch et al. (2010), $-0.47 \pm 0.36$ and $-1.21 \pm 0.96 \% \mathrm{yr}^{-1}$, for the periods 1985-2000 and 2000-2005, respectively are also similar to our estimates, $-0.5 \pm 0.05$ and $-2.0 \pm 0.25 \% \mathrm{yr}^{-1}$.

Direct comparisons with other inventories are difficult, because most values are calculated for different periods. Interpretation differences, mapping errors, and the number of glaciers may also contribute to discrepancies among inventories. Other glacier area change estimates for the Canadian Rocky Mountains include -15 to $-25 \%$ from ca. 1950 to 2000 (Luckman and Kavanagh, 2000; DeBeer and Sharp, 2007), and -22 to $-36 \%$ from 1975 to 1998 (Demuth et al., 2008). Jiskoot et al. (2009) determined rates of area change of $-9 \%$ per decade and $-19 \%$ per decade for the Clemenceau and Chaba icefields, respectively, from 1985 to 2001. Our rate of area change over the same period for the Chaba Icefield is $-7 \%$ per decade, which is closer to Jiskoot et al.'s (2009) rate of area change for the Clemenceau Icefield. The latter is not covered by the IBCS maps. However, Jiskoot et al. (2009) used different source data for the 1985 glacier extents with a larger extent of some glaciers of the Chaba Icefield than we used for our 1985 glacier extents.

Glaciers in the northern and southern Coast Mountains of British Columbia shrank less ( -8 to $-10 \%$ from 19852005) than those in the Canadian Rocky Mountains, primarily due to the larger sizes of glaciers in the former area and possible influence of a maritime climate (Bolch et al., 2010). Most inventories of Northern Hemisphere glaciers are based on the last half of the 20th century and indicate area losses from 7 to $32 \%$ (Kääb et al., 2002; Paul et al., 2004; Granshaw and Fountain, 2006; Bolch, 2007). Two studies report glacier area change over longer periods: a $23 \%$ decrease between 1930 and 2003 for Jotunheimen, Norway (Andreassen et al., 2008); and $49 \%$ and $35 \%$ decreases between 1850 and the mid-1970s for glaciers in the New Zealand and European Alps, respectively (Hoelzle et al., 2007). 


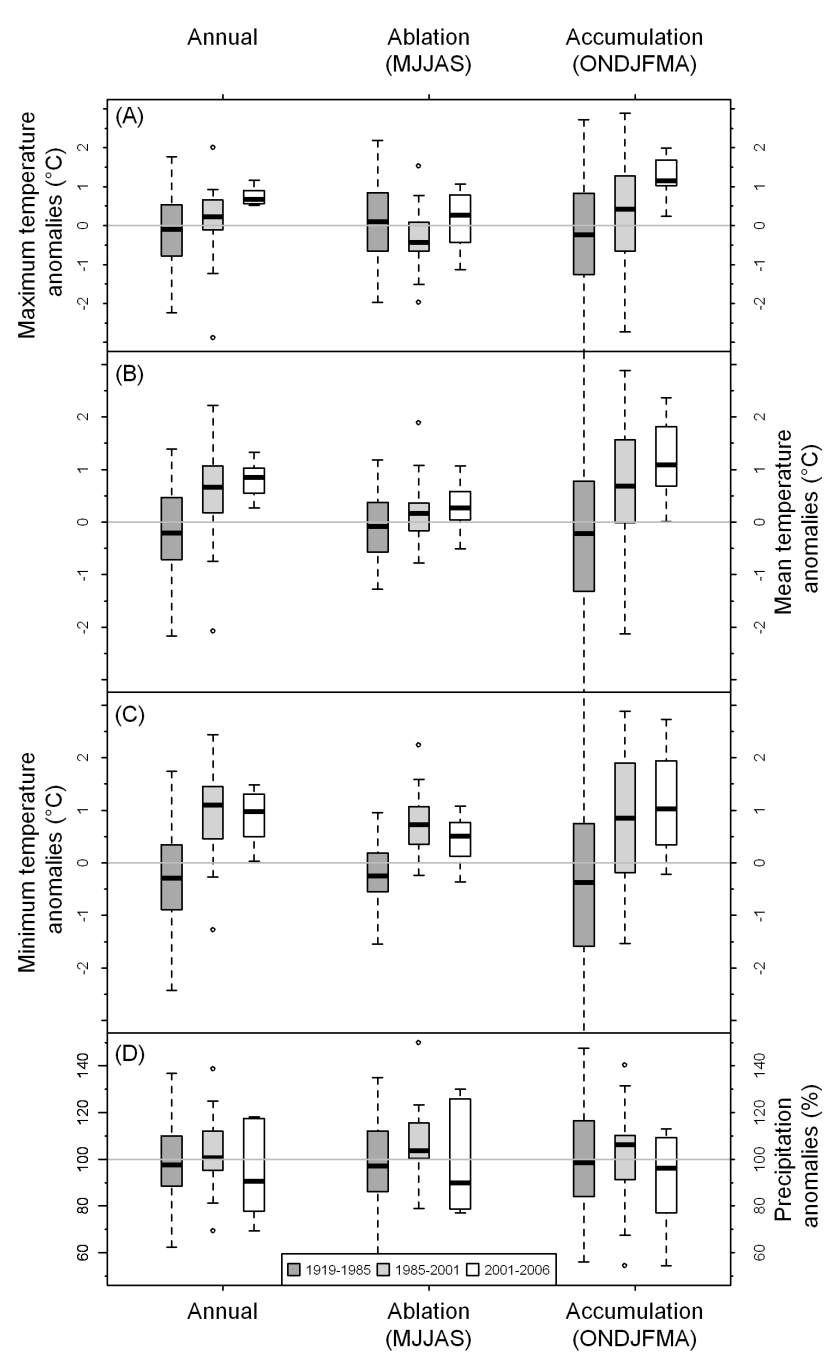

Fig. 9. (A) Maximum, (B) mean, and (C) minimum temperature anomalies calculated for the average annual, ablation, and accumulation seasons for the periods 1919-1985, 1985-2001, and 20012006. (D) Precipitation anomalies calculated from precipitation during the hydrologic year (annual), and precipitation during the ablation and accumulation seasons for the same periods. The climatic mean is based on the period 1919-2006.

Of the glaciers inventoried in this study, glaciers less than $1.0 \mathrm{~km}^{2}$ lost the greatest percentage of their area. This result is consistent with those of the majority of the studies mentioned previously (e.g. Kääb et al., 2002; Paul et al., 2004; Granshaw and Fountain, 2006; Demuth et al., 2008). Granshaw and Fountain (2006) argue that this difference is due to the high area-to-volume ratio of small glaciers; for the same ablation rate, small glaciers would shrink faster. Another possible explanation is that small glaciers have a higher perimeter-to-area ratio, which makes them more susceptible to radiation from the surrounding terrain (Demuth et al., 2008; Jiskoot and Mueller, 2012). The greatest absolute area loss is in the $1.0-5.0 \mathrm{~km}^{2}$ class (Table 3). DeBeer and Sharp (2007) found that the high loss of area for glaciers in this size class is due both to the large number of glaciers of this size and the high losses of individual glaciers. An apparent trend in our data and in other published datasets (e.g. Kääb et al., 2002; Granshaw and Fountain, 2006; DeBeer and Sharp, 2007; Andreassen et al., 2008) is the increase in the variability of relative area change with decreasing glacier size (Fig. 6). This trend likely arises from non-climatic factors such as local topography, hypsometry, and variable debriscover, which may have a stronger influence on a glacier's response than regional climate (Kääb et al., 2002; Granshaw and Fountain, 2006; DeBeer and Sharp, 2007; Hoffman et al., 2007; Andreassen et al., 2008; Jiskoot et al., 2009).

\subsection{Area change with glacier attributes}

Absolute area change is most closely related to glacier size, but moderate correlations were also found with glacier slope and minimum elevation. These attributes are typically associated with larger glaciers, which lost the greatest absolute area over the period 1919-2006. Correlations between absolute area change and slope were also noted by Andreassen et al. (2008) and Jiskoot et al. (2009). Glaciers with low slopes $\left(<15^{\circ}\right)$ or low mean/median elevations lost the greatest percentage of their area, possibly reflecting differences in glacier dynamics and mass balance. Glaciers with low slopes may transfer mass more slowly to low elevations (i.e. they have long response times) where the majority of area loss occurs (Jiskoot et al., 2009). Ablation at low elevations, that occurs persistently faster than ice is transmitted down slope, can result in a large loss of area over time. Glaciers situated at low elevations are subject to warmer temperatures and potentially higher ablation rates compared to glaciers at high elevations. Over time high mass loss can translate into large relative area loss. Relative area change by region, basin, or side of the Continental Divide are similar among the attribute classes.

Relative area change between 1919 and 2006 for glaciers less than $1.0 \mathrm{~km}^{2}$ in area was similar to all other glaciers, but other trends emerged from the insolation and aspect attributes. Relative area loss was high for south- to west-facing glaciers, which receive high insolation, but small glaciers at high elevations lost the least relative area. DeBeer and Sharp (2007) found that small glaciers $\left(<0.5 \mathrm{~km}^{2}\right)$ experienced little or no change. Smaller glaciers tend to be located in more sheltered locations, at high elevations, at sites with reduced insolation or that have inputs from avalanching or wind (DeBeer and Sharp, 2007; Demuth et al., 2008). This sheltering effect may be present in our data, because although we observed large percentages of area loss for small glaciers, the $0.5-1.0 \mathrm{~km}^{2}$ class lost the highest percentage, not the smallest class $\left(<0.1 \mathrm{~km}^{2}\right)$. 


\subsection{Area change with climate}

Rates of area loss for the period 1985-2001 are lower than those for the period 1919-1985 (Table 3), but there is a possible overestimation of glacier area for the 2001 glacier area. A few of the 2000-2002 Landsat images have some late-lying snow that hindered delineation of some small glaciers and high elevation glacier extents. This late-lying snow only accounts for errors of $\pm 3 \%$ in the extents determined by Bolch et al. (2010), and is smaller than the error estimates (Table 2). The rate of area loss between 2001 and 2006 is three to four times the rates of the previous two periods. However, the first period (1919-1985) spans more than six decades and includes shorter intervals with different rates of loss, whereas the last period (2001-2006) is a half decade long and may be a period characterized by high rates of loss. So the direct comparison of area change rates referring to periods of differing length has to be done with caution, since the shorter the period analyzed, the less robust are the trends.

The period 1919-1985 was a time of highly variable climate. Around the 1920s, some glaciers in the Canadian Rocky Mountains were still near their Little Ice Age maximum extents (Field, 1948). From the 1920s to the 1950s, climate was warm and dry (Field, 1948; Heusser, 1956; Luckman and Kavanagh, 2000), while the second half of the period, was cool and wet (Henoch, 1971; Luckman and Kavanagh, 2000). Unfortunately, these different climates are not captured in the climate data, because the differences are averaged out over the long period. Positive temperature anomalies (ca. $0.5^{\circ} \mathrm{C}$ ) and high accumulation season precipitation anomalies (ca. 110\%) characterize the period 1985-2001. Warmer temperatures during this period are also mentioned in other studies (Pelto, 2006; Hoffman et al., 2007). Positive temperature anomalies $\left(>0.5^{\circ} \mathrm{C}\right.$ above average) and low precipitation anomalies (ca. 90\%) characterize the period 20012006. However, this period is only five years long and may have been influenced by short term variations in climate.

Area change is not an immediate response to a change in climate. The response time of a glacier depends on its size, attributes, and topography. We thus cannot quantitatively relate our area changes to climate, but we do see similarities in the two over the periods of decades, which are evidenced by the correspondence between rates of area change and the temperature and precipitation anomalies (Fig. 7 and 9). From 1919 to 2006, temperatures increased, precipitation decreased, and rates of area loss increased.

\section{Conclusions}

We used IBCS maps from 1919 and a portion of the Western Canada glacier inventory from 1985, 2001, and 2006 to determine area change of glaciers in the central and southern Canadian Rocky Mountains. The main uncertainties and errors arise from data quality and availability. Errors in the
IBCS maps included mapped snow patches, inconsistent glacier extents, and incorrect termini. Although large errors are associated with the IBCS maps, they still are a useful source of information on early 20th century glacier extents and elevations. Over long periods, glacier changes are significantly larger than the errors in the maps. Other sources of error in the most recent datasets include late-lying snow, shadows, and debris cover, which hinder glacier delineation. Data for the entire study area were available for only four temporal datasets, and thus area change could only be evaluated over three periods. Averaging over the period 19191985 obscures short-term glacier change and climate variability.

Area change is influenced predominately by glacier size, with large glaciers losing the most absolute area and small glaciers losing the greatest percentage of their area. Variability in relative area change increases with smaller glaciers, suggesting that local non-climatic factors modulate the response of these glaciers to climate change. Aspect, slope, and elevation influence the amount of area change experienced by the glaciers. In addition to the attributes considered in this study, future research should focus on other attributes related to glacier type and source of nourishment (i.e. outlet, cirque, avalanche-fed, and debris-covered glaciers), in order to better understand how these factors influence glacier change.

Acknowledgements. Research funding was provided by the Natural Sciences and Engineering Research Council of Canada (Canadian Graduate Scholarship to C. Tennant and Discovery Grant to B. Menounos), the University of Northern British Columbia (Graduate Entrance Scholarship to C. Tennant), and the Western Canadian Cryospheric Network (funded by the Canadian Foundation for Climate and Atmospheric Sciences). This research benefited from stimulating discussions with Brian Luckman. Joanne Lee, Lyssa Maurer, Brenden McBain, and Natalie Saindon helped rectify and digitize the Interprovincial Boundary Commission Survey maps. We thank M. Pelto, H. Jiskoot, F. Paul, and one anonymous reviewer for constructive and insightful comments that have strengthened the paper.

Edited by: S. Marshall

\section{References}

Andreassen, L. M., Paul, F., Kääb, A., and Hausberg, J. E.: Landsatderived glacier inventory for Jotunheimen, Norway, and deduced glacier changes since the 1930s, The Cryosphere, 2, 131-145, doi:10.5194/tc-2-131-2008, 2008.

Barry, R. G.: The status of research on glaciers and global glacier recession: A review, Prog. Phys. Geog., 20, 285-306, doi:10.1191/0309133306pp478ra, 2006.

BC Ministry of Environment, Land and Parks: British Columbia specifications and guidelines for geomatics, release 2.0, Victoria, BC, 1992.

BC Ministry of Forests: Zone and Provincial Classification Reports, available at: http://www.for.gov.bc.ca/hre/becweb/ 
resources/classificationreports/provincial/index.html

(last access: 18 May 2011), 1998.

Bolch, T.: Climate change and glacier retreat in Northern Tien Shan (Kazakhstan/Kyrgyzstan) using remote sensing data, Global Planet. Change, 56, 1-12, 2007.

Bolch, T., Menounos, B., and Wheate, R.: Landsat-based inventory of glaciers in Western Canada, 1985-2005, Remote Sens. Environ., 114, 127-137, doi:10.1016/j.rse.2009.08.015, 2010.

Daly, C., Gibson, W. P., Taylor, G. H., Johnson, G. L., and Pasteris, P.: A knowledge-based approach to the statistical mapping of climate, Clim. Res., 22, 99-113, 2002.

DeBeer, C. M. and Sharp, M. J.: Recent changes in glacier area and volume within the Southern Canadian Cordillera, Ann. Glaciol., 46, 215-221, 2007.

Demuth, M., Pinard, V., Pietroniro, A., Luckman, B., Hopkinson, C., Dornes, P., and Comeau, L.: Recent and past-century variations in the glacier resources of the Canadian Rocky Mountains: Nelson River system, Terra Glacialis, Special Issue: Mountain Glaciers and Climate Changes of the Last Century, 27-52, 2008.

Denton, G.: Glaciers of the Canadian Rocky Mountains, in: Mountain Glaciers of the Northern Hemisphere, edited by: Field, W. O., United States Army Cold Regions Research and Engineering Laboratory, Hanover, NH, 603-653, 1975.

Dyurgerov, M. B. and Bahr, D. B.: Correlations between glacier properties: Finding appropriate parameters for global glacier monitoring, J. Glaciol., 45, 9-16, 1999.

Dyurgerov, M. B. and Meier, M. F.: Twentieth century climate change: Evidence from small glaciers, P. Natl. Acad. Sci., 97, 1406-1411, 2000.

Farr, T. G., Rosen, P. A., Caro, E., Crippen, R., Duren, R., Hensley, S., Kobrick, M., Paller, M., Rodriguez, E., Roth, L., Seal, D., Shaffer, S., Shimada, J., Umland, J., Werner, M., Oskin, M., Burbank, D., and Alsdorf, D.: The Shuttle Radar Topography Mission, Rev. Geophys., 45, RG2004, doi:10.1029/2005RG000183, 2007.

Field, W. O. J.: Glacier observations in the Canadian Rockies, Can. Alpine J., 32, 99-114, 1948.

$\mathrm{Fu}$, P. and Rich, P. M.: A geometric solar radiation model with applications in agriculture and forestry, Comput. Electron. Agr., 37, 25-35, 2002.

Granshaw, F. D. and Fountain, A. G.: Glacier change (1958-1998) in the North Cascades National Park Complex, Washington, USA, J. Glaciol., 52, 251-256, 2006.

Hauer, F., Baron, J. S., Campbell, D. H., Fausch, K. D., Hostetler, S. W., Leavesley, G. H., Leavitt, P. R., McKnight, D. M., and Stanford, J. A.: Assessment of climate change and freshwater ecosystems of the Rocky Mountains, USA and Canada, Hydrol. Process., 11, 903-924, 1997.

Henoch, W. E. S.: Estimate of glaciers' secular (1948-1966) volumetric change and its contribution to the discharge in the upper North Saskatchewan River basin, J. Hydrol., 12, 145-160, 1971.

Heusser, C.: Postglacial environments in the Canadian Rocky Mountains, Ecol. Monogr., 26, 263-302, 1956.

Hoelzle, M., Chinn, T., Stumm, D., Paul, F., Zemp, M., and Haeberli, W.: The application of glacier inventory data for estimating past climate change effects on mountain glaciers: A comparison between the European Alps and the Southern Alps of New Zealand, Global Planet. Change, 56, 69-82, 2007.
Hoffman, M. J., Fountain, A. G., and Achuff, J. M.: 20th-century variations in area of cirque glaciers and glacierets, Rocky Mountain National Park, Rocky Mountains, Colorado, USA, Ann. Glaciol., 46, 349-354, 2007.

Interprovincial Boundary Commission: Report of the Commission Appointed to delimit the boundary between the provinces of Alberta and British Columbia: from 1913-1916, Part I, Office of the Surveyor General, Ottawa, ON, 1917.

Jiskoot, H. and Mueller, M. S.: Glacier fragmentation effects on surface energy balance and runoff: field measurements and distributed modelling, Hydrol. Process., 26, 1862-1876, 2012.

Jiskoot, H., Curran, C. J., Tessler, D. L., and Shenton, L. R.: Changes in Clemenceau Icefield and Chaba Group glaciers, Canada, related to hypsometry, tributary detachment, lengthslope and area-aspect relations, Ann. Glaciol., 50, 133-143, 2009.

Jóhannesson, T., Raymond, C. F., and Waddington, E. D.: Timescale for adjustments of glaciers to changes in mass balance, J. Glaciol., 35, 355-369, 1989.

Jost, G., Moore, R. D., Menounos, B., and Wheate, R.: Quantifying the contribution of glacier runoff to streamflow in the upper Columbia River Basin, Canada, Hydrol. Earth Syst. Sci., 16, 849-860, doi:10.5194/hess-16-849-2012, 2012.

Kääb, A., Paul, F., Maisch, M., Hoelzle, M., and Haeberli, W.: The new remote-sensing-derived Swiss glacier inventory: II. First results, Ann. Glaciol., 34, 362-366, 2002.

Kienzle, S. W., Nemeth, M. W., Byrne, J. M., and MacDonald, R. J.: Simulating the hydrological impacts of climate change in the upper North Saskatchewan River basin, Alberta, Canada, J. Hydrol., 412, 76-89, 2012.

Luckman, B. H. and Kavanagh, T.: Impact of climate fluctuations on mountain environments in the Canadian Rockies, Ambio, 29, 371-380, 2000.

Marshall, S. J., White, E. C., Demuth, M. N., Bolch, T., Wheate, R., Menounos, B., Beedle, M. J., and Shea, J. M.: Glacier water resources on the eastern slopes of the Canadian Rocky Mountains, Can. Water Resour. J., 36, 109-134, doi:10.4296/cwrj3602823, 2011.

Mbogga, M., Hamann, A., and Wang, T.: Historical and projected climate data for natural resource management in Western Canada, Agr. Forest Meteorol., 149, 881-890, 2009.

Mitchell, T. D. and Jones, P. D.: An improved method of constructing a database of monthly climate observations and associated high-resolution grids, Int. J. Climatol., 25, 693-712, 2005.

Moore, R. D. and Demuth, M. N.: Mass balance and streamflow variability at Place Glacier, Canada, in relation to recent climate fluctuations, Hydrol. Process., 15, 3473-3486, 2001.

Moore, R. D., Fleming, S. W., Menounos, B., Wheate, R., Fountain, A., Stahl, K., Holm, K., and Jakob, M.: Glacier change in Western North America: influences on hydrology, geomorphic hazards and water quality, Hydrol. Process., 23, 42-61, doi:10.1002/hyp.7162, 2009.

Ommanney, C. S. L.: Glaciers of the Canadian Rockies, in: Satellite image atlas of glaciers of the world, edited by: Ferrigno, J. and Williams Jr., R. S., US Geological Survey, Denver, CO, J199_ J289 (USGS Professional Paper 1386-J.), 2002.

Osborn, G., Stockmal, G., and Haspel, R.: Emergence of the Canadian Rockies and adjacent plains: A comparison of physiography between end-of Laramide time 
and the present day, Geomorphology, 75, 450-477, doi:10.1016/j.geomorph.2005.07.032, 2006.

Paul, F., Kääb, A., Maisch, M., Kellenberger, T. W., and Haeberli, W.: Rapid disintegration of Alpine glaciers observed with satellite data, Geophys. Res. Lett., 31, L21402, doi:10.1029/2004GL020816, 2004.

Paul, F., Barry, R. G., Cogley, J. G., Frey, H., Haeberli, W., Ohmura, A., Ommanney, C. S. L., Raup, B., Rivera, A., and Zemp, M.: Recommendations for the compilation of glacier inventory data from digital sources, Ann. Glaciol., 50, 119-126, 2009.

Pelto, M. S.: The current disequilibrium of North Cascade glaciers, Hydrol. Process., 20, 769-779, doi:10.1002/hyp.6132, 2006.

Raup, B., Kääb, A., Kargel, J. S., Bishop, M. P., Hamilton, G., Lee, E., Paul, F., Rau, F., Soltesz, D., Khalsa, S. J. S., Beedle, M., and Helm, C.: Remote sensing and GIS technology in the Global Land Ice Measurements from Space (GLIMS) Project, Comput. Geosci., 33, 104-125, 2007.

Schiefer, E., Menounos, B., and Wheate, R.: An inventory and morphometric analysis of British Columbia glaciers, Canada, J. Glaciol., 54, 551-560, doi:10.3189/002214308785836995, 2008.
Shea, J. M., Marshall, S. J., and Livingston, J. M.: Glacier distributions and climate in the Canadian Rockies, Arct. Antarct, Alp. Res., 36, 272-279, 2004.

Stahl, K. and Moore, R. D.: Influence of watershed glacier coverage on summer streamflow in British Columbia, Canada, Water Resour. Res., 42, W06201, doi:10.1029/2006WR005022, 2006.

Wang, T., Hamann, A., Spittlehouse, D., and Aitken, S. N.: Development of scale-free climate data for western Canada for use in resource management, Int. J. Climatol., 26, 383-397, 2006.

Wang, T., Hamann, A., Spittlehouse, D. L., and Murdock, T. Q.: ClimateWNA - high-resolution spatial climate data for Western North America, J. Appl. Meteorol. Clim., 51, 16-29, doi:10.1175/JAMC-D-11-043.1, 2012.

Wheeler, A. O.: The application of photography to the mapping of the Canadian Rocky Mountains, Can. Alpine J., 2, 76-87, 1920.

Wheeler, J. O.: A. O. Wheeler and mapping in the Canadian Cordillera, in: Explorations in the History of Canadian Mapping: A Collection of Essays, edited by: Farrell, B. and Desbarats, A., Assoc. Can. Map Libraries Archive, Ottawa, ON, 211-222, 1988. 